\title{
STABILIZING INSTRUMENTS OF THE FINANCIAL SAFETY NET IN POLAND
}

\author{
INSTRUMENTY STABILIZUJĄCE SIECI \\ BEZPIECZEŃSTWA FINANSOWEGO W POLSCE
}

\author{
Kinga Stępień ${ }^{1}$ \\ WOJSKOWA AKADEMIA TECHNICZNA \\ WYDZIAŁ LOGISTYKI
}

\begin{abstract}
The article describes the shape of the financial safety net in the banking system in Poland. The Polish National Bank, Financial Supervision Commission and the Bank Guarantee Fund instruments were described in respect of the stability of the banking system. The study also included functions (instruments) and of the Committee of Financial Stability as a collective body set up to ensure cooperation and coordination between the financial safety net institutions to support and maintain the stability of the domestic financial system.
\end{abstract}

Streszczenie: W artykule scharakteryzowano kształt sieci bezpieczeństwa finansowego w systemie bankowym w Polsce. Analizie opisowej poddano instrumenty Narodowego Banku Polskiego, Komisji Nadzoru Finansowego oraz Bankowego Funduszu Gwarancyjnego w aspekcie stabilności systemu bankowego. W opracowaniu uwzględniono także funkcje (instrumenty) i kompetencje Komitetu Stabilności Finansowej jako organu kolegialnego powołanego do zapewnienia współpracy i koordynacji działań

1 Kinga Stępień - dr nauk ekonomicznych, adiunkt naukowo-dydaktyczny w Instytucie Systemów Bezpieczeństwa i Obronności na Wydziale Logistyki Wojskowej Akademii Technicznej w Warszawie. W pracy naukowej zajmuje się zagadnieniami związanymi z bezpieczeństwem finansowym i ekonomicznym, stabilnością finansową oraz konwergencją systemów finansowych. W obszarze dydaktycznym prowadzi zajęcia z Ekonomii, Geoekonomii i Finansów. Jest autorką i współautorką publikacji z zakresu nauki finansów i bezpieczeństwa; e-mail: kinga.stepien@wat.edu.pl.

Kinga Stępień - PhD in economic sciences, scientific and didactic assistant professor at the Institute of Security and Defence Systems at the Faculty of Logistics of the Military University of Technology in Warsaw. In her scientific work she deals with issues related to financial and economic security, financial stability and convergence of financial systems. In the didactic area teaches Economics, Geoeconomics and Finance. She is the author and co-author of publications in the field of finance and security science; e-mail: kinga.stepien@wat.edu.pl. 
instytucji sieci bezpieczeństwa finansowego na rzecz wspierania i utrzymania stabilności krajowego systemu finansowego.

Keywords: financial safety net, stability of banking system, stabilizing instruments, institutions of financial safety net in Poland.

Słowa kluczowe: sieć bezpieczeństwa finansowego, stabilność systemu bankowego, instrumenty stabilizacyjne, instytucje sieci bezpieczeństwa finansowego w Polsce.

\section{Characteristics of the institutional shape of the financial safety net banking system in Poland}

Functioning of the safety net in the Polish legal system is regulated by law. A special role and sovereignty of these institutions are guaranteed by law by isolating them from the executive power in relation to other financial institutions. In case of other financial institution, the state imposes the requirements of financial information reliability and the preparation of periodic financial statements which are subject to verification by independent auditors. The net of financial stability in its institutional scope includes ministry of finance, central banks, financial market supervision institutions and system of deposits guarantee. In Poland, the responsible authorities are as follows: government (the minister responsible for financial institutions - Minister of Finance - $M F)$, the Polish National Bank $(P N B)$, the Financial Supervision Authority (FSA) and the Bank Guarantee Fund $(B G F)$. These entities also establish the Financial Stability Committee (FSC), which aims, among others, at macro-prudential supervision and coordination of the situation in the event of a crisis on the Polish financial market.

The role of government in the safety net can be described as comprehensive. It is performed in a wide range as a regulatory function and the disposal of public funds. From the point of view of the stability of the banking sector it should be noted that the minister of finance, as the only entity in the safety net, has a legislative initiative and can provide banks with significant amounts in case of serious difficulties of a systemic nature. In 2006 by the Market Development Council was appointed by the Minister of Finance as a consultative and advisory body on issues of the financial market ${ }^{2}$. Its location by the minister responsible for financial institutions is to contribute to the realization of its effective policy development in the area of the financial market. In particular, the functions of the Council include formulating proposals for action aimed at the development of the financial market in terms of adjusting

2 The composition of the Council, due to the nature of the forum and its representativeness, includes representatives of financial market participants, including institutions supervising the market. The works of the Financial Market Development Council is directed by the Minister of Finance or the Secretary of State designated by the Minister. To work within FMDC other people on the rights of members and experts are invited. To develop specific issues the Chairman of the Council may appoint teams and working groups consisting of experts of the subjects analyzed. 
the Polish financial market to international requirements and standards, minimizing the systemic risk associated with the operation of the financial market, increasing the efficiency of the financial market and increasing its security, as well as building public confidence in financial market institutions ${ }^{3}$.

The central role in the safety net is assigned to the central bank. Operations for the financial stability of the domestic financial system have become the statutory task of the PNB in $2008^{4}$. Financial safety of the banks is a major area of concern of the PNB for this reason that it performs the functions of lender of the last instance. The stability of the banking system is also a prerequisite for the smooth functioning of the cash settlements. However, the key issue in the case of the PNB is the existence of the relations between price stability, which is the main statutory goal of the PNB and financial stability. These relations could be a two-way street. Decisions within the monetary policy may have implications for financial stability, and its threats and interference may adversely affect on the level of prices and monetary policy.

An integral institution in the safety net is the supervisor of the financial market. The concept of the FSA is part of the integrated financial market supervision model, whose main statutory objective is to provide proper functioning of the market, its stability, safety and transparency, confidence in the financial market and to ensure protection of the interests of market participants ${ }^{5}$.

The key element of the safety net is the deposit guarantee system, along with the institution of anti-bankruptcy protection. The main aim of these systems is to protect the deposits of bank customers. In addition, the BGF conducts support activities involving the granting of repayable financial assistance and purchase of receivables of banks, which there was a risk of insolvency ${ }^{6}$.

\section{Stabilizing instruments of the financial safety net institutions in Poland}

\subsection{Instruments stabilizing of the $P N B$}

In the literature there is a consensus on the crucial role of the central bank in stabilizing the financial system. In the most general terms, these arguments can be summarized in the triad. The central bank is the sole issuer of money, and

3 Statement of the Minister of Finance of 17 November 2014 on the uniform text of the Minister of Finance on the establishment of Financial Market Development Council, Official Journal of Minister of Finance, Warsaw, 19 November 2014. Pos. 50.

4 Art. 3. The Law on the National Polish Bank of August 29, 1997 (OJ 1997 No. 140, item. 938, as amended).

5 Art. 2. Act on Financial Market Supervision of 21 July 2006 (OJ 2006 No 157, item. 1119, as amended).

6 Art. 4. The Law on the Bank Guarantee Fund of 14 December 1994 (OJ 1995 No. 4 pos. 18, as amended). 
also it organizes, regulates and monitors the smooth functioning of the payment system. Its role in stabilizing the financial system is also reflected in the provision of liquidity ${ }^{7}$. The main statutory purpose of the PNB is to maintain price stability. Financial stability is strongly correlated with the primary objective of the $P N B$ for this reason that the financial system is the main channel of transmission of monetary policy impulses to the real economy. In addition, the central bank in Poland is legally designated as the entity responsible for creating the conditions necessary for the development of the banking system and taking actions in favor of the stability of the national financial system ${ }^{8}$. Instability of the financial system may adversely affect the effective conduct of monetary policy. Financial stability depends on the stability of the currency and vice versa. However, financial stability should not be perceived as an effect of monetary stability ${ }^{9}$.

The PNB is equipped with a set of instruments for stabilizing the financial system, which can be classified as: instruments of monetary policy implementation, information policy and an analysis of the situation in the financial system, instruments to support liquidity, regulation and supervision, organization and supervision of the payment system and crisis management.

The monetary policy run by the PNB is based on the selection and implementation of monetary macro-economic objectives by regulating the supply and demand for money ${ }^{10}$. The $P N B$ does not have a direct impact on the assigned statutory target in the form of maintaining a stable price level, and for its implementation a set of the following instruments is used: open market operations, reserve requirements and credit-deposit operations. However, it can be concluded that the main instrument of monetary policy is currently an impact on interest rates. Thereby, stabilizing operation of the instrument affects financial stability.

Among the instruments for ensuring the stability of the financial system an important role play monitoring and an analysis of the financial system in Poland combined with communication with the environment (information policy). These activities are aimed at strengthening financial stability by providing information about risk factors and an assessment of the resilience of the financial system at risk. Promotion and dissemination of this knowledge should help to shape inflation expectations, which can be

7 G. J. Schinasi, Responsibility of central banks for stability in financial markets, Working Paper, 2003, No. 121, IMF, Washington D.C. p. 5 and next; T. Padoa-Schioppa, Central banks and financial stability: exploring a land in between, [in:] The transformation of the European financial system, V. Gaspar, P. Hartman, O. Sleijpen, [ed.], Second ECB Central Banking Conference, European Central Bank, Frankfurt am Main, 2003, p. 274.

8 Art. 3 paragraph. 2 point 6 and 6a of the Act of August 29, 1997. Polish National Bank (OJ 2013. Pos. 908).

9 M. Bordo i in., Aggregate Price Shocks and Financial Instability: A Historical Analysis, Working Paper 2000-005B http://research.stlouisfed.org/wp/2000/2000-005.pdf, September 2001, Federal Reserve Bank of St. Louis.

10 Polityka pieniężna. Cele, strategie, instrumenty, W. Przybylska-Kapuścińska (red.), Wyd. Akademii Ekonomicznej w Poznaniu, Poznań 2002, p.5. 
regarded today as the most important form of the impact of the central bank on financial market participants. The use of this tool increases the probability of a spontaneous adjustment of the behavior of financial market actors taking excessive risks, without the interference of public entities in the market mechanism. In this respect the operational instruments are used, and they include: a public announcement of the objective of stabilizing the financial system, the publication of reports on financial stability and reports on the development of the financial system, as well as communication of bank authorities with the public in the form of messages and speeches. Information policy is associated with the implementation of the PNB strategy of direct inflation targeting.

The central bank traditionally acts as a lender of the last chance to provide liquidity to institutions which are threatened. In this way, it corrects the instability in the financial market by creating the reserved money or deducting excess liquidity from the market. Such activities are carried out in case of the threat to liquidity and stability of the whole financial system and for the individual players in the market. The choice of an instrument to support liquidity always depends on the assessment of the liquidity of the financial system and the actions taken. The distinguishing feature of the central bank as a lender of the last chance is the rate at which the central bank may react to the problem of a single bank resulting from loss of liquidity ${ }^{11}$.

The function of supervision and regulation in the current model position of integrated supervision of the FSA comes in a practical aspect to supervision of the payment systems by the $P N B$ and therefore, an access to information on the functioning of payment and clearing systems. The NBP has a so-called oversight system policy, whose main aim is to ensure the smooth and safe functioning of the payment system and to ensure compliance of the functioning of supervised systems and services with the law. In this way, these activities are a part of a more broadly worded general tasks of the NBP associated with maintaining the stability of the national financial system, the maintenance of public confidence in the national currency and ensuring the protection and transmission channels of monetary policy ${ }^{12}$. In particular, the NBP monitors the functioning of supervised systems and services, assesses them in terms of implementing these systems for supervisory purposes and, if necessary, may take regulatory actions aimed at introducing changes in their functioning.

Instruments used in crisis situation management are varied and are not standard. They take the form of discretionary actions dependent on the size of the risks to financial stability. The most frequently ways of crisis management in the financial system used by banks we need to include the function of lender of the last chance,

11 I. Kraś, Polityka banku centralnego a bezpieczeństwo finansowe państwa, [w:] „Przegląd Strategiczny”, 2013, no. 1, p. 193.

12 Polityka sprawowania przez Narodowy Bank Polski nadzoru systemowego w zakresie systemu płatniczego, NBP, Warszawa, 2015. 
information policy, under which one can distinguish communication with the market, and moral persuasion and a decision about the lack of intervention ${ }^{13}$.

\section{Instruments stabilizing of the $F S A$}

The Polish Financial Supervision Authority is an institution monitoring all segments of the financial market, including the activities of subordinate commercial banks. Its primary objective is to ensure the stability and safety of the banking sector, as well as the creation and control of the prudential norms targeted at banks. The FSA is very important for the functioning of the market and ensuring financial stability. It supervises the activities of not only the banking and insurance sectors, but also the institutions related to the pension sector, capital market and entities that deal with the handling of electronic money. The FSA exercises integrated financial supervision over:

- the banking sector,

- the capital market,

- the insurance market,

- the pension market,

- electronic money institutions.

The Authority was established on 19 September 2006 on the basis of the Act of 21 July 2006 on the supervision of the financial market. It took the powers of the Securities and Exchange Commission Insurance and Pension Funds, and from 1 January 2008 the powers of the Commission for Banking Supervision. These bodies oversaw different segments of the financial market before was an integrated supervisory authority brought to life. The creation of an independent, integrated financial supervision was conditioned by changes in the market, and in particular:

- increasing role of substitute products and hybrid from different segments of the financial market,

- increasing competition from shadow banks,

- emergence of new models and distribution channels for financial services,

- presence in the market of conglomerates and financial groups focusing on its structure entities offering products from all segments of the financial market,

- the growing role of foreign investors in the banking and insurance market ${ }^{14}$. The scope of competences of the Financial Supervision Authority may be considered as wide. Its tasks include in particular supervision over the financial market

13 O. Szczepańska, P. Sotomska-Krzysztofik, M. Pawliszyn, Banki centralne wobec kryzysów w systemie bankowym, „Materiały i Studia”, zeszyt nr 179, NBP, Warszawa, listopad 2004, s. 9.

14 M. Capiga, W. Gradoń, G. Szustak, Sieć bezpieczeństwa finansowego, CeDeWu, Warszawa 2010, s. 43. 
and taking actions for the proper functioning of the financial market, undertaking activities aimed at developing the financial market and its competitiveness and undertaking educational and information steps on the functioning of the financial market. The FSA is also involved in drafting legislation in the field of financial market supervision, insurance and pensions and work on creating opportunities for amicable and conciliatory settlement of disputes between financial market participants, in particular disputes arising from contractual relationships between entities subject to supervision by the Authority and recipients of services provided by these entities. In addition, the FSA performs other tasks defined by relevant laws.

The statutory purpose of the FSA is to ensure the proper functioning of the financial market, its stability, safety and transparency, confidence in the financial market and to ensure protection of the interests of market participants. An analysis of competences of the FSA indicates that the fundamental objectives of supervision in the banks specified in the Banking Law is:

- ensuring the safety and stability of the banking system,

- ensuring protection of the interests of financial market participants,

- control of capital groups,

- quick response to the problems of the consumer and the market ${ }^{15}$.

As a part of its control functions in relation to the banking sector, the Financial Supervision Authority uses a broad set of instruments which aim to contribute to the implementation of its main statutory purpose. These instruments are based on the analysis and study of the different business areas of the bank, mainly on:

- assessment of the financial position of banks (the study of solvency, asset quality, liquidity payment, the financial result of banks),

- study of the quality of bank management (risk management, internal control system),

- consistency study of loans, cash loans, letters of credit, bank guarantees and sureties, and issued bank securities with the applicable regulations,

- study of security and timely repayment of loans and cash, the study comply with the limits referred to the art. 71.1 and art. 79a of Banking Act and the assessment of the process of identifying, monitoring and control of large exposures,

- study of compliance with standards of acceptable risk in the banks' operations, risk management (adapting to the type and scale of the bank's process for identifying and monitoring risks) - and reporting with an acceptable risk in the banks business,

- assessment of estimating, maintenance and review of internal capital. The evaluation of entities covered by the supervision takes place using the so-called BION method (audit and board evaluation), which is a tool

15 Art. 133.1. Act of 29 August 1997 of Banking Law (Journal of Laws of 2015, item 128). 
to assist supervision precautions head (risk-based). The main principles of BION relate to methods of scoring of banks expanded and developed for the assessment of market, insurance, pension and capital institutions ${ }^{16}$.

The Banking Guarantee Fund (the Fund) is an important element in the structure of the safety net in Poland and fulfills functions which can be summarized in the following triad: guarantee, supportive and analytical. This institution works for the safety and stability of banks and cooperative credit unions, and increasing confidence in the financial system ${ }^{17}$.

As a part of the guarantee function the Fund guarantees its depositors the payment to the statutory amount of 100 thousand euro. In the Polish guarantee system the participation is mandatory for national banks (cooperative and commercial), as well as branches of foreign banks, which are established outside the EU, unless they belong to any guarantee system or the level of the guarantee system to which they belong is lower than this provided in Poland. From 29 November 2013 the BGF took its guarantee over money on the accounts held by the cooperative savings and credits institutions.

Deposits in banks that operate in Poland in the form of a branch of a credit institution with the hub in another EU country are covered by guarantees of institutions of the home country of the bank. The list of entities whose the BGF deposits covers a warranty is closed. The warranties of Polish deposit protection scheme include PLN deposits and foreign currency of natural persons, legal entities, including local governments, other entities with legal capacity, as well as school savings associations and employee assistance and loan. From this system there are excluded deposits of the Treasury and financial institutions: banks, investment and pension funds, insurers and brokerage houses. The exclusion from the protection also applies to deposits of senior management of the bank endangered with bankruptcy (to the level of directors of the Central Office and the shareholders of the bank, if they have at least 5 per cent of interest). Statutorily protected amount of 100 thousand euro refers to the sum of all deposits of a given depositor gathered in one bank.

Funds for the payment of guaranteed amounts are collected in individual banks covered by the guarantee scheme in a special, dedicated fund. In the event of bank failure and the need to make payments to its clients the guaranteed amounts, other banks participating in the system make the relevant payments to the account of the Fund. The funds accumulated in the banks are not the only source of financing

16 M. Capiga, W. Gradoń, G. Szustak, Systemy wczesnego ostrzegania w ocenie działalności instytucji finansowych, CeDeWu, Warszawa 2013, s. 140.

17 Legislation adopted in the Act on the BGF are fully harmonized with the Directive 94/19/EC of the European Parliament and of the Council of 30 May 1994 on deposit guarantee schemes, amended by Directive 2009/14/EC of 11 March 2009, amending Directive 94/19/EC on depositguarantee schemes with regards to the coverage level and the payout delay. 
of the Fund. In case when they are insufficient, the Fund may, among others, use own funds to raise funds in the form of grants or loans from the state budget or take out a short-term loan in the PNB.

In addition to the guarantee activity the Fund also performs the assistance functions for banks, which are threatened with danger of insolvency. It has the ability to provide them with financial aid for independent rehabilitation or to take over the bank threatened by another healthy bank or other shareholders. For this goal all banks contribute to the Fund so-called an annual fee. Assistance activities of the $B G F$ allows to limit the situations in which there is a bankruptcy and the payment of guaranteed funds is necessary.

Since its establishment in 1995 the Fund made the payment of guaranteed funds to customers of ninety-four banks in bankruptcy, mainly cooperative (eighty-nine cases), but also for the five commercial banks.

Stabilization instruments used by the BGF to carry out the functions of the warranty, assistance and analytics can be classified as follows:

- a return to the amount specified by the Act on the $B G F$ of the funds held in bank accounts in the case of conditional guarantee to the bank which is a member of the deposit guarantee system, • from 29 November 2013 a return to the level specified by the Act on the $B G F$ of the funds held in the accounts of the cooperative savings and credit, in the case of the condition to guarantee money,

- providing financial assistance to banks located in case of insolvency, or the acquisition of shares of banks,

- assisting the cooperative societies and savings and loan in case of danger of insolvency and to support the restructuring process for these banks,

- granting the guarantees to domestic banks implementing rehabilitation program to increase the bank's own funds and, in the case of execution of this guarantee - the acquisition or subscription of stocks, bonds or bank securities,

- gathering and analyzing information on the entities covered by the guarantee system, including the preparation of analyzes and forecasts for the banking sector and banks sector.

The $B G F$ financial assistance to banks in a state of danger of insolvency is implemented in the form of preferential, low-interest loans with a long grace period for repayment. The loans can be granted to the bank in financial difficulties on the so-called independent rehabilitation or to a bank in a good position to take over the bank in difficulty. The funds for assistance activities come from the banks obliged to annual fees to the assistance fund collected in the BGF. This fee is non-refundable, created on an ex ante basis. The collected funds not involved at the time in support are invested in safe securities whose return increases the possibility of intervention of the Fund. The annual fee is indirectly dependent on the scale of the risks taken by banks as well as the assessment of the safety of the banking sector. In order to create the possibility 
of assessing the scale of the risk and the assessment of the condition of individual banks and the banking sector, the $B G F$ is equipped with analytical facilities. The aim of this analysis should be to assess the risk of bank failures based on early warning systems.

The FSC was created and included in the safety net in Poland in 2008 as a body for cooperation and coordination of activities of institutions of safety net to support and maintain the stability of the domestic financial system ${ }^{18}$. The action of the FSC is scheduled between the idea of creating effective national systems of crisis management in the EU Member States as a result of the financial crisis of 2007. Originally the main goal of the FSC was to ensure cooperation in supporting and maintaining the stability of the financial system in Poland through the exchange of information, opinions and assessments of the situation in the domestic and international financial system and the coordination of activities in this area. The FSC consisted of the $M F$ as Chairman of the Committee, the Chairman of the PNB and the Chairman of the FSA. The main function of stabilizing the FSC at that time was to make assessments of the situation in the domestic financial system and on international markets and to ensure the proper flow of information about significant events constituting a threat to the stability of the domestic financial system between the members of the Committee. Stabilizing action of the Committee could also be realized through the development and adoption procedures of cooperation in the event of a threat to the stability of the domestic financial system.

The comparative analysis of historical and current competence of the FSC indicates that the Act on macro-prudential oversight of the financial system and crisis management in the financial system expanded the functional scope of the FSC. It should be noted that the purpose of macro-prudential supervision is, in particular, strengthening the resilience of the financial system in the event of materialization of systemic risk, and support for a long-term a sustainable economic growth of the country. In the event of an imminent threat to the financial stability, the FSC is also to be responsible for tasks related with crisis management. Crisis management in the financial system includes action to maintain or restore financial stability in the event of a direct threat to this stability. So that the FSC is now a body that is responsible for the formation of macro-prudential policy and coordination of activities within the framework of crisis management. In summary we can say that as a result of the introduction of new prudential rules for financial institutions the competence of the FSC increased ${ }^{19}$.

The Committee consists of the Minister of Finance, President of the NPB, the Chairman of the Financial Supervision Authority and Chairman of the Board of the Fund. The works of macro-prudential supervision are conducted by the President of the PNB

18 The Act of 7 November 2008 on the Financial Stability Committee (OJ 2008. No. 2009 pos.1317).

19 Act on macro-prudential supervision is to adjust Polish law to EU directives issued after the financial crisis (i.e. The CRD IV Directive and CRR Regulation). 
which provides support for the Committee. In the area of crisis management the work of the Committee is chaired by the Minister of Finance and the support of the Committee is provided by the Ministry of Finance.

The primary function of the FSC is to identify, assess and monitor systemic risks arising in the financial system or its environment. The FSC identifies financial institutions that could generate risks of the financial system as a whole or its parts. Additionally, the FSC has initiated actions to mitigate the identified risks to financial stability. In connection with the implementation of this function, the Committee has the so-called "soft impact" instrument. In order to perform its tasks the FSC may appoint positions and give recommendations. The positions are presented in the identification of sources of systemic risk in the financial system or its surroundings and are designed to draw attention to the identified threat to financial stability. They can be addressed to all entities in the financial system or its components, as well as the institutions taking part in the FSC. Recommendations can be formulated for the need to take action in order to reduce systemic risk and to the institution belonging to the FSC. Recipients of recommendations are required to take the recommended action or explain the reasons for not taking that action. Recommendations may concern, in particular the introduction or re-calibrating of macro-prudential instruments by the minister responsible for financial institutions (Ministry of Finance) on its way of taking regulatory actions by the FSC.

\section{Conclusion}

On the basis of considerations some conclusions can be formulated. The safety and stability of the financial system is a particular good. In order to provide it the most important role is played by the institutions of safety net, which include the ministry of finance, central banks, institutions of financial market supervision and a deposit guarantee system. In Poland such bodies are the government (the minister responsible for financial institutions - Minister of Finance - $M F$ ), the Polish National Bank $(N B P)$, the Financial Supervision Authority (FSA) and the Bank Guarantee Fund $(B G F)$. These entities form the Financial Stability Committee (FSC), which aims, among others, at macro-prudential supervision and coordination of the situation in the event of a crisis in the Polish financial market.

The $P N B$ is a key institution in the safety net in Poland. Financial stability is connected with the main objective of the $P N B$ as the impulses transmission of monetary policy to the real economy occurs through the financial system. The PNB is legally responsible for creating the conditions necessary for the development of the banking system and taking actions in favor of the stability of the domestic financial system. It has a number of preventive and intervention instruments. 
The objective of the Financial Supervision Authority is to supervise all financial market segments, including the activities of the subordinate commercial banks. The main objective of the Authority is to ensure the stability and security of the banking sector, as well as the creation and control of the prudential norms targeted at banks. The special role of the FSC in ensuring financial stability stems also from the fact that it supervises not only the activities of the banking and insurance sectors, but also the institutions related to the pensions sector, capital market and entities that deal with the handling of electronic money ${ }^{20}$.

The Bank Guarantee Fund operates warranty, it also has a means of serving of the financial assistance to banks having problems in terms of solvency. For the implementation of the guarantee function the instrument for the payment of depositors of guaranteed funds are used in case of their unavailability to the specified statutory amount. The purpose of the function of assistance is financial support for banks in an emergency of their solvency. This assistance may be in the form of loans, guarantees and warranties.

The Fund is responsible for the formation of macro-prudential policy and coordination of activities within the framework of crisis management. Its competences include the identification, assessment and monitoring of systemic risk arising in the financial system or its environment.

\section{REFERENCES}

[1] Bordo M. ANd others., Aggregate Price Shocks and Financial Instability: A Historical Analysis, Working Paper 2000-005B, http://research.stlouisfed.org/wp/2000/2000-005.pdf, September 2001, Federal Reserve Bank of St. Louis.

[2] Capiga M., Gradoń W., Szustak G., Sieć bezpieczeństwa finansowego, CeDeWu, Warszawa 2010.

[3] Capiga M., Gradoń W., Szustak G., Systemy wczesnego ostrzegania w ocenie działalności instytucji finansowych, CeDeWu, Warszawa 2013.

[4] Filar W., StęPIEŃ K., Rola NBP jako kluczowej instytucji sieci bezpieczeństwa finansowego w zapewnianiu stabilności systemu bankowego w Polsce, [in:] Bunt i reforma, ed. G. Osiki, Wyd. Homini, Kraków 2011.

[5] KA£UZIŃsKa V., Bank centralny wobec kwestii stabilności systemu finansowego, [in:] Ruch prawniczy, ekonomiczny i socjologiczny, Rok LXX1 - zeszyt 1, 2009. Kraś I., Polityka banku centralnego a bezpieczeństwo finansowe państwa, in: „Przegląd Strategiczny”, 2013, no. 1. Padoa-Schioppa T., Central banks and financial stability: exploring a land in between, [in:] The transformation of the European financial system, Gaspar, V., Hartman, P., Sleijpen, O., [ed.], Second ECB Central Banking Conference, European Central Bank, Frankfurt am Main, 2003. Polityka pieniężna. Cele, strategie, instrumenty, ed. W. Przybylska-Kapuścińska, Wyd. Akademii Ekonomicznej w Poznaniu, Poznań 2002.

20 FSA is not provided with the financial resources allocated to assist banks or intervene in the banking market. It has, however, significant analytical capabilities to diagnose economic and financial situation of individual banks. It may also request information from banks, control them, impose sanctions on them, and provide the applicable regulatory requirements. 
[6] Polityka sprawowania przez Narodowy Bank Polski nadzoru systemowego w zakresie systemu płatniczego, NBP, Warszawa, 2015.

[7] Schinasi G.J., Responsibility of central banks for stability in financial markets, Working Paper, 2003, No. 121, IMF, Washington D.C.

[8] Smaga P., Pomiar stabilności banku centralnego, [in:] „Bezpieczny Bank”, 2014, 4(57).

[9] Solarz J.K., Międzynarodowy system finansowy. Analiza instytucjonalno -porównawcza, Biblioteka Menedżera i Bankowca, Warszawa 2001, pp. 183-184.

[10] Szczepańska O., Stabilność finansowa jako cel banku centralnego, Wyd. Naukowe Scholar, Warszawa 2008.

[11] Szczepańska O., Sotomska-Krzysztofik P., Pawliszyn M., Pawlikowski A., Instytucjonalne uwarunkowania stabilności finansowej na przykładzie wybranych krajów, „Materiały i Studia”, no. 173, NBP, Warszawa, kwiecień 2004.

[12] Szczepańska O., Sotomska-Krzysztofik P., Pawliszyn M., Banki centralne wobec kryzysów w systemie bankowym, „Materiały i Studia”, Zeszyt nr 179, NBP, Warszawa, listopad 2004.

[13] Zygierewicz M., Stabilność finansowa, [w:] „Annales Universitatis Mariae Curie-Skłodowska Lublin - Polonia", Sectio H, 2013, Vol. XL VII, 3.

[14] Statement of the Minister of Finance of 17 November 2014 on the uniform text of the Minister of Finance on the establishment of Financial Market Development Council, Official Journal of Minister of Finance, Warsaw, 19 November 2014, Pos. 50.

[15] The Law on the Polish National Bank of August 29, 1997. (OJ 1997 No. 140, item. 938, as amended).

[16] The Act on Financial Market Supervision of 21 July 2006. (OJ 2006 No 157, item. 1119, as amended). The Law on the Bank Guarantee Fund of 14 December 1994. (OJ 1995 No. 4 pos. 18, as amended). The Act of 29 August 1997 on Banking Law (Journal of Laws of 2015. Poz.128).

[17] The Act of 7 November 2008 on the Financial Stability Committee (OJ 2008. No. 2009 poz.1317).

[18] The law of 5 August 2015 on macro-prudential oversight of the financial system and crisis management in the financial system (OJ 2015, pos. 1513). 
